\title{
Recruiting egg donors online: an analysis of in vitro fertilization clinic and agency websites' adherence to American Medicine guidelines Society for Reproductive
}

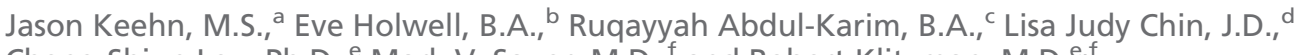 \\ Cheng-Shiun Leu, Ph.D., ${ }^{e}$ Mark V. Sauer, M.D., ${ }^{f}$ and Robert Klitzman, M.D. ${ }^{\text {,ff }}$ \\ ${ }^{a}$ Masters Program in Bioethics and ${ }^{b}$ Post-Baccalaureate Pre-Med Program, Columbia University, New York, New York; \\ c Department of Bioethics, National Institutes of Health, Bethesda, Maryland; ${ }^{d}$ HIV Center for Clinical and Behavioral \\ Studies, New York Psychiatric Institute and Columbia University, New York, New York; ${ }^{\mathrm{e}}$ Columbia University Mailman \\ School of Public Health, New York, New York; and ${ }^{f}$ Columbia University College of Physicians \& Surgeons, New York, \\ New York
}

Objective: To examine compliance with ethical guidelines of the American Society for Reproductive Medicine (ASRM) regarding traitbased payment variation, presentation of risks, and minimum recruitment age.

Design: In June 2010, we systematically examined 207 websites, of which 102 were egg donor agency or IVF clinic websites that both recruited online and displayed compensation amounts.

Setting: The Internet.

Patient(s): None.

Intervention(s): Not applicable.

Main Outcome Measure(s): Mention of increased payment for particular donor traits, recruitment age less than 21 years, noting risks to donors.

Result(s): Of the 102 sites, considerable numbers were noncompliant with ASRM's guidelines that prohibit varying compensation based on a donor's traits (34\%), and recommend an age of 21 years or older (41\%), and presentation of risks alongside compensation (56\%). Trait-based payment variation was associated with being an agency rather than a clinic, location in the West, not being endorsed by ASRM or Society of Assisted Reproductive Technology (SART), and referring to ASRM's guidelines about compensation. Of sites mentioning traits, prior donation success was the most commonly paid for trait (64\%).

Conclusion(s): Our data, the first to systematically analyze agency and clinic websites reveal that many do not follow ASRM's guidelines. These data have critical implications for policy, practice, and research, suggesting needs for consideration of possible changes in guidelines, and/or improvements in compliance and monitoring by ASRM or others. (Fertil Steril ${ }^{\circledR}$ 2012;98:995-1000. (C2012 by American Society for Reproductive Medicine.)

Key Words: Egg donor agency, financial compensation of oocyte donors, egg donor compensation, commodification of egg donors, ethics, gamete donation

Discuss: You can discuss this article with its authors and with other ASRM members at http:// fertstertforum.com/keehnj-egg-donors-asrm-guidelines/

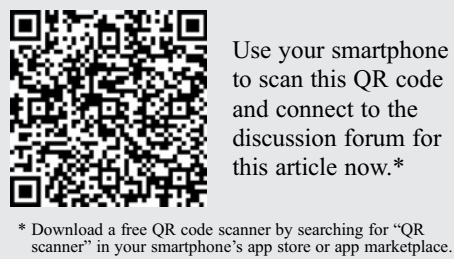

Received December 13, 2011; revised May 25, 2012; accepted June 27, 2012; published online July 27, 2012.

J.K. has nothing to disclose. E.H. has nothing to disclose. R.A.-K. has nothing to disclose. L.J.C. has nothing to disclose. C.-S.L. has nothing to disclose. M.V.S. has nothing to disclose. R.K. has nothing to disclose.

The opinions expressed here are the authors' and do not reflect the policies and positions of the National Institutes of Health, the U.S. Public Health Service, or the U.S. Department of Health, or the Ethics Committee of the American Society for Reproductive Medicine.

Reprint requests: Robert Klitzman, M.D., Department of Clinical Psychiatry, Masters of Bioethics Program, Columbia University, 1051 Riverside Drive \#15, New York, NY 10032 (E-mail: rlk2@ columbia.edu).

Fertility and Sterility® Vol. 98, No. 4, October 2012 0015-0282/ $\$ 36.00$

Copyright @2012 American Society for Reproductive Medicine, Published by Elsevier Inc.

http://dx.doi.org/10.1016/j.fertnstert.2012.06.052

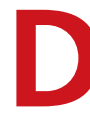
ebates are continuing to evolve on the use of compensation provided to women for donating oocytes, but few data exist concerning actual practices. Egg donation remains an important component of assisted reproductive technology (ART), yet physicians and scholars continue to argue whether compensation should 
be allowed at all, and if so, what sums are too high, whether to standardize or cap payment amounts, as well as what exactly is being purchased (i.e., the donor's service vs. the eggs themselves) $(1,2)$ These issues are widely reported in the media including Newsweek (3), The Economist (4), and The New York Times (5), but scant data have been published on the practice of donor compensation in the United States (6).

Approaches to regulating these practices vary between countries. In the United States, the fertility industry remains "free market" and the American Medical Association looks to professional societies, such as American Society for Reproductive Medicine (ASRM), to essentially self-regulate providers of ART (7). In 2007 ASRM issued guidelines to affirm that, "financial compensation of women donating oocytes for infertility therapy ... is justified on ethical grounds" (8) and then issued a series of guidelines meant to suggest appropriate practice parameters. Compensation for egg donation is believed to be important because without it the supply of gametes to treat infertility may dwindle and the rights of the donor to receive due compensation may be violated. There are even arguments that there should not be the current ASRM guideline suggesting a $\$ 10,000$ ceiling on egg donor compensation. Indeed, a recent class action lawsuit was filed against the ASRM, the Society for Assisted Reproductive Technology (SART), and the Pacific Fertility Center for alleged "price fixing" by suggesting an upper limit on amounts of compensation.

The Internet, in particular, is an extremely important forum for egg donor recruitment (9), as it is for medical research recruitment in general (10); however, many aspects of its role in recruiting egg donors remain unknown. Only three studies have considered the Internet with regard to egg donor recruitment-Luk and Petrozza (11) systematically examined compensation differences by region. Holster (12) looked at donor qualifications, donor databases, website appearance, and compensation amounts, and Johnson (13) systematically investigated anonymity policies. But several issues have not been addressed, and we thus set out to do so, specifically to 1) verify compliance with ASRM's published guidelines on trait-based payment among both clinics and agencies, 2) detail the types and frequency of traits desired, 3) examine disclosure of risks and age minimums, and 4) follow the realistic steps a prospective donor might take through an online search engine that includes both agencies and clinics she might consider.

\section{MATERIALS AND METHODS}

We systematically reviewed American fertility clinics and donor-matching agencies involved in the recruitment of egg donors by analyzing their websites. To simulate the steps that a prospective egg donor might take to find donation opportunities, we conducted an online search, in June 2010, through Google, entering the term egg donation.

As shown in Table 1 , we collected a list of 414 websites from within the first 300 results returned from Google. Within the first 20 results, a large health directory website (www.ihr.com) appeared, as did the websites of SART (www.sart.org) and ASRM (www.asrm.org). Therefore we included all clinic and agency websites listed on these three

\section{TABLE 1}

Recruitment websites surveyed.

Relevant web hits for "egg donation"

Sites systematically assessed (50\%)

Fertility clinics or agencies

Actively recruits online or by phone

Displays compensation (total sample)

Keehn. Recruiting egg donors online. Fertil Steril 2012.

sites, and removed any duplicate site that appeared both on one of these three sites, and within the first 300 hits of the search results. We also eliminated sites that were not directly related to the recruitment of egg donors, such as news articles and informational websites.

Three coders independently read a randomly selected sample of websites to familiarize themselves with the website content and develop a systematic coding manual. Afterward, every second website was selected from the master list, totaling 207. Of these 207 sites, each one was assigned to two coders for analysis. Each coder examined the websites independently for qualitative and quantitative data and compared results, discussing ambiguities in the coding to arrive at a consensus. In this review of 207 sites, we removed 13 sites that were not egg donor agencies or clinics, such as egg banks, research facilities, and affiliate networks. For the remaining 194 websites, we coded 5 broad categories:

- Background Information: clinic versus agency; and geographic region of the country (14)

- Donor Eligibility Restrictions: minimum and maximum age for participation; minimum education requirements

- ASRM Endorsement: its endorsement by ASRM (agency) or membership in SART (clinics); whether it refers to ASRM's guidelines when discussing compensation

- Commodification of Donor Traits: whether a site mentioned desirable donor traits; if so, what they were and whether they compensated more of them

- Disclosure of health risks: any mention of short-term health risks (e.g., ovarian hyperstimulation syndrome [OHSS]) (15) or long-term health risks (e.g., risks to future fertility through severe infection or ovarian torsion and tissue necrosis) (16-18)

We used three categories to describe sites in terms of how they mentioned compensation for donor traits: 1) no mention; 2) explicitly paying more for certain traits; and 3) only mentioning traits as "preferred" or "in demand" (i.e., but not stating explicitly that these traits would receive more compensation). We assessed the frequencies of the binary website characteristic across these three compensation categories, and the strength of association in each cross tabulation, and used a logistic regression to compare sites that did not mention traits versus those that paid more for traits, as well as sites that did not mention traits versus those that did mention traits. We did not obtain Institutional Review Board approval, as we did not collect data concerning any human subjects and assessed only publicly available websites. 


\section{RESULTS}

Of the 194 clinic and agency sites examined, only 102 (53\%) actively recruited donors online (i.e., provided a registration form or a number to call) and displayed compensation amounts (Table 1). Of these sites, 34\% explicitly mention paying donors higher compensation for particular traits (Table 2). An additional 15\% discuss traits as "preferred" or "in demand," and 51\% did not mention donor traits.

Of the 50 websites mentioning traits, 80\% mentioned prior donation success, and 64\% paid more for it; $42 \%$ mentioned education level, and 18\% paid more for it; 34\% mentioned ethnicity, and 12\% paid more for it; $28 \%$ mentioned creative or athletic ability, and $12 \%$ paid more for it; $16 \%$ mentioned physical appearance, and 4\% paid more for it; and 8\% mentioned standardized test scores and 2\% paid more for it (Table 3).

As shown in column 1 of Table 2, clinics and agencies were equally represented among websites that recruited donors online and presented compensation information ( $\mathrm{n}=51$ for each). Of these sites, 24\% were not SART or ASRM approved, and 33\% were in the West. Of the websites, $74 \%$ made no mention of ASRM's ethical guidelines on financial compensation to egg donors, 41\% accepted donors less than 21 years, and 22\% had a minimum educational requirement to donate (high school or above). Of websites, 56\% did not discuss any short-term risks (e.g., OHSS, infection, or hospitalization), 77\% did not mention possible emotional or psychological risks of egg donation, and 92\% did not acknowledge any possible risk to future fertility (e.g., damage to the ovaries).

Websites that explicitly paid more for certain traits were more likely than those that did not mention traits to be agencies (odds ratio $[\mathrm{OR}]=20.0, P<.001$ ), non-ASRM/ SART approved (OR $=7.05, P<.001$ ), and based in the West $(\mathrm{OR}=2.87, P<.001)$. They were also more likely to refer to ASRM's ethical compensation guidelines $(\mathrm{OR}=7.14$, $P<.001$ ), to have a minimum education requirement to donate $(\mathrm{OR}=5.56, P=.003)$, and as trends, to recruit donors less than 21 years of age $(O R=2.34, P=.07)$, and not to acknowledge possible risks to a donor's future fertility (OR $=0.19, P=.053)$.

Sites that showed any trait-based preference (either as "in demand" or explicitly paying for them) were more likely than those sites that did not mention traits to be agencies, non-ASRM/SART approved, and be based in the West (Table 2). They were also more likely to refer to ASRM's ethical compensation guidelines and to recruit donors less than 21 years of age.

\section{DISCUSSION}

This study, the first to analyze systematically trait-based compensation among websites of egg donation agencies and clinics, indicates that many agencies and clinics do not fully comply with ASRM's guidelines on financial compensation of oocyte donors.

The ASRM guidelines on compensation are meant, in part, to address the ethical concerns of compensating for egg donation. These concerns include the possible exploitation of donors and the devaluation of personhood by "commodifying" human life. The ASRM's guidelines address the concern of commodification of human life by stating that compensation should reflect the "time, inconvenience, and discomfort" associated with the oocyte donation process, which should be "distinguished from payment for oocytes themselves ..., [and] to avoid putting a price on human gametes or selectively valuing particular human traits, compensation should not vary according to ... the outcome of prior donation cycles, or the donor's ethic or other personal characteristics."

However, our study found that 49\% of websites violate the guidelines of ASRM's intent to "avoid ... selectively valuing particular human traits." Specifically, 34\% of websites offer to pay donors higher compensation for certain traits, clearly deviating from ASRM's principle of structuring compensation based on the time, inconvenience, and discomfort of egg donation, and avoiding payment for eggs themselves, and an additional 15\% of sites mentioned certain traits only as "preferred" or "in demand."

The most commonly preferred trait, prior donation success, does not follow ASRM's guideline to avoid compensation based on "the number or outcome of prior donation cycles." Although working with past donors can achieve recruitment and screening efficiencies for clinics and can enhance a donor's safety by referencing her history of stimulation response, paying donors a premium for having previously donated does carry some unique ethical concerns: not only does it selectively value fertility as a trait, but it also incentivizes donors to repeat the procedure. For example, anecdotally, some websites increased their payment to donors by $\$ 500$ for each successful prior donation. Considering ASRM recommends limiting a woman's total donation cycles to six in her lifetime, in part to reduce potential health risks, this practice may create "undue influence and exploitation," which ASRM seeks to avoid when "structur[ing] the provisions of incentives."

Paying premiums for the desired traits related to personal characteristics that reflect professional and social aspirations raises concerns including fears of eugenics, potential social inequities related to genetics, and parents potentially placing undue expectations on children subsequently born (19). However, paying a premium for characteristics such as ethnicity, is a different story, as it is completely understandable that parents often would want children to be of the same race as them. When an infertile couple uses an egg donor as opposed to adopting a child, the infertile couple can, if they desire, remain private about the nature of their conception if the child resembles them. In addition, certain ethnic groups may be less inclined to donate and in those cases, paying more for such an ethnic background may be inevitable. Such an increase in payment would, theoretically, help address the likelihood of a dearth in egg donors for infertile couples of that ethnic background.

Paying more for behavioral or subjective traits, such as cognitive, physical, or artistic ability, also reinforces inaccurate knowledge about genetics. Whereas geneticists have determined that cognitive ability has a substantial genetic component (20), traits are nonetheless still not linked to one gene as in Mendelian genetics (2). Donor eligibility 
Characteristics of websites by their mention of desired egg donor traits $(n=102)$.

\section{Ways donor traits are mentioned}

\begin{tabular}{|c|c|c|c|c|c|c|c|c|}
\hline Characteristics of websites & $\begin{array}{l}\text { Total sample } \\
\text { no. }(\%)^{\mathrm{a}}\end{array}$ & $\begin{array}{l}\text { No mention } \\
\text { of traits }\end{array}$ & $\begin{array}{l}\text { Explicitly pays } \\
\text { more for traits }\end{array}$ & $\begin{array}{l}\text { Mentioned only } \\
\text { as "preferred" } \\
\text { or "in demand" }\end{array}$ & $\begin{array}{l}\text { No mention vs. pays } \\
\text { more }^{\mathrm{b}} \text {, OR }(95 \% \mathrm{Cl})\end{array}$ & $P$ value & $\begin{array}{l}\text { No mention vs. all } \\
\text { others }^{c}, \text { OR }(95 \% \mathrm{Cl})\end{array}$ & $P$ value \\
\hline $\begin{array}{l}\text { Total sample } \\
\text { Organization information } \\
\text { Type }\end{array}$ & $102(100.0)$ & $52(51.0)$ & $35(34.0)$ & $15(15.0)$ & & & & \\
\hline $\begin{array}{l}\text { Clinic, no. (\%) } \\
\text { Agency, no. (\%) } \\
\text { West coast vs. rest of the country }\end{array}$ & $\begin{array}{l}51(50.0) \\
51(50.0)\end{array}$ & $\begin{array}{l}40(78.4) \\
12(23.5)\end{array}$ & $\begin{array}{c}5(9.8) \\
30(58.8)\end{array}$ & $\begin{array}{l}6(11.8) \\
9(17.6)\end{array}$ & $20.00(16.36-62.89)$ & $<.001$ & $11.82(4.67-29.94)$ & $<.001$ \\
\hline $\begin{array}{l}\text { Northeast, south, midwest, no. (\%) } \\
\text { West coast/Pacific, no. (\%) }\end{array}$ & $\begin{array}{l}64(67.0) \\
32(33.0)\end{array}$ & $\begin{array}{r}43(67.2) \\
8(25.0)\end{array}$ & $\begin{array}{l}10(15.6) \\
21(65.6)\end{array}$ & $\begin{array}{l}11(17.2) \\
3(9.4)\end{array}$ & $2.87(1.73-4.77)$ & $<.001$ & $2.25(1.41-3.60)$ & $<.001$ \\
\hline $\begin{array}{l}\text { Regulatory endorsement } \\
\text { SART or ASRM approval }\end{array}$ & & & & & & & & \\
\hline $\begin{array}{l}\text { Approved, no. (\%) } \\
\text { Not approved, no. (\%) } \\
\text { Does site reference ASRM guidelines or } \\
\text { compensation? }\end{array}$ & $\begin{array}{l}78(76.0) \\
24(24.0)\end{array}$ & $\begin{array}{r}47(60.3) \\
5(20.8)\end{array}$ & $\begin{array}{l}20(25.6) \\
15(62.5)\end{array}$ & $\begin{array}{r}11(14.1) \\
4(16.7)\end{array}$ & $7.05(2.26-22.03)$ & $<.001$ & $5.76(1.95-17.04)$ & $<.002$ \\
\hline $\begin{array}{l}\text { No mention of ASRM, no. (\%) } \\
\text { Refers to ASRM, no. (\%) }\end{array}$ & $\begin{array}{l}75(74.0) \\
27(26.0)\end{array}$ & $\begin{array}{r}46(61.3) \\
6(22.2)\end{array}$ & $\begin{array}{l}18(24.0) \\
17(63.0)\end{array}$ & $\begin{array}{r}11(14.7) \\
4(14.8)\end{array}$ & $7.14(2.44-20.0)$ & $<.001$ & $5.56(2.0-14.29)$ & $<.001$ \\
\hline $\begin{array}{l}\text { Recruitment requirements for donation } \\
\text { Age minimum (y) }\end{array}$ & & & & & & & & \\
\hline $\begin{array}{l}21-22, \text { no. }(\%) \\
18-20, \text { no. }(\%) \\
\text { Education minimum }\end{array}$ & $\begin{array}{l}56(59.0) \\
39(41.0)\end{array}$ & $\begin{array}{l}33(58.9) \\
15(38.5)\end{array}$ & $\begin{array}{l}16(28.6) \\
17(43.6)\end{array}$ & $\begin{array}{l}7(12.5) \\
7(17.9)\end{array}$ & $2.34(0.94-5.84)$ & $<.07$ & $2.30(1.00-5.30)$ & $<.003$ \\
\hline $\begin{array}{l}\text { No mention, no. (\%) } \\
\text { Has minimum requirement, no. (\%) }\end{array}$ & $\begin{array}{l}80(78.0) \\
22(22.0)\end{array}$ & $\begin{array}{r}47(58.8) \\
5(22.7)\end{array}$ & $\begin{array}{l}22(27.5) \\
13(59.1)\end{array}$ & $\begin{array}{r}11(13.8) \\
4(18.2)\end{array}$ & $5.56(1.76-17.52)$ & $<.003$ & $4.84(1.63-14.44)$ & $<.005$ \\
\hline $\begin{array}{l}\text { Risks } \\
\text { Short-term risks discussed }\end{array}$ & & & & & & & & \\
\hline $\begin{array}{l}\text { Yes, no. (\%) } \\
\text { No, no. (\%) } \\
\text { Psychological/emotional risks discussed }\end{array}$ & $\begin{array}{l}45(44.0) \\
57(56.0)\end{array}$ & $\begin{array}{l}21(46.7) \\
31(54.4)\end{array}$ & $\begin{array}{l}19(42.2) \\
16(28.1)\end{array}$ & $\begin{array}{r}5(11.1) \\
10(17.5)\end{array}$ & $0.57(0.21-1.36)$ & NS & $0.734(0.34-1.61)$ & NS \\
\hline $\begin{array}{l}\text { Yes, no. (\%) } \\
\text { No, no. (\%) } \\
\text { Risks to future fertility acknowledged }\end{array}$ & $\begin{array}{l}23(23.0) \\
79(77.0)\end{array}$ & $\begin{array}{l}14(60.9) \\
38(48.1)\end{array}$ & $\begin{array}{r}6(26.1) \\
29(36.7)\end{array}$ & $\begin{array}{r}3(13.0) \\
12(15.2)\end{array}$ & $1.78(0.61-5.20)$ & NS & $1.68(0.65-4.33)$ & NS \\
\hline $\begin{array}{l}\text { Yes, no. }(\%) \\
\text { Noe }^{e} \text {, no. }(\%)\end{array}$ & $\begin{array}{c}8(8.0) \\
94(92.0)\end{array}$ & $\begin{array}{r}2(25.0) \\
50(53.2)\end{array}$ & $\begin{array}{r}6(75.0) \\
29(30.9)\end{array}$ & $\begin{array}{c}0(0) \\
15(16.0)\end{array}$ & $0.19(0.04-1.02)$ & $<.053$ & $0.29(0.06-1.53)$ & NS \\
\hline \multicolumn{9}{|c|}{$\begin{array}{l}\text { Note: ASRM = American Society for Reproductive Medicine; NS = not significant; SART = Society of Assisted Reproductive Technology. } \\
\text { a For some website characteristics, the data were not discussed on all websites, reducing the sample below } 102 \text {. } \\
\text { b Binary regression analysis comparing sites that do not mention donor traits and those that explicitly pay more for them. } \\
\text { c Binary regression analysis comparing sites that do not mention donor traits to those that do. } \\
\text { d Excludes six sites that had a national presence in multiple regions around the country. } \\
\text { e "No risks acknowledged" refers to both sites that do not mention future fertility risk as well as sites that discuss it but assert that no risk }\end{array}$} \\
\hline
\end{tabular}




\section{TABLE 3}

\begin{tabular}{|c|c|c|c|}
\hline Desired donor trait & $\begin{array}{c}\text { Not } \\
\text { mentioned }\end{array}$ & $\begin{array}{l}\text { Paid } \\
\text { more for }\end{array}$ & $\begin{array}{c}\text { "Preferred" } \\
\text { or "in } \\
\text { demand" }\end{array}$ \\
\hline Prior donation success, no. (\%) & $10(20)$ & $32(64)$ & $8(16)$ \\
\hline Ethnicity, no. (\%) & $33(66)$ & $6(12)$ & $11(22)$ \\
\hline Test scores, no. (\%) & $46(92)$ & $1(2)$ & $3(6)$ \\
\hline Education level, no. (\%) & $29(58)$ & $9(18)$ & $12(24)$ \\
\hline Physical appearance, no. (\%) & $42(84)$ & $2(4)$ & $6(12)$ \\
\hline Creative/athletic ability, no. (\%) & $36(72)$ & $6(12)$ & $8(16)$ \\
\hline
\end{tabular}

requirements also reflect trait selection. The $22 \%$ of sites with education requirements were more likely to pay premiums for traits. This practice underscores that pedigrees, as opposed to reproductive services, are indeed being purchased, and it may present additional concerns of discrimination, as screening out less educated donors prevents certain groups of women from the option of even participating in egg donation.

To address concerns of exploiting donors, ASRM guidelines state, "to discourage improper decisions to donate oocytes," donors should, "receive accurate and meaningful information on the potential physical, psychological, and legal effects of oocyte retrieval and donation" (8). Accordingly, the guidelines suggest, "limit[ing] donors to those who are 21 or older," and ensuring, "advertisements for donors [that] are accurate and responsible ... [such that] if financial ... benefits are noted ... and the existence of risks and burdens also ... [are] acknowledged" (8).

Our data present only websites that indicated financial benefits and found that most did not present risks, either short term $(56 \%)$, long term $(92 \%)$, or psychological/emotional (77\%). Presumably, clinicians discuss risks in an informed consent process before initiating the procedure; however, research indicates that individuals make risk/benefit decisions based on their first impressions, which may often occur on websites (9). Although the American Medical Association has issued guidelines concerning certain aspects of online health information (21), these guidelines address how conventional patients, who seek medical care for their own health benefit, should be informed. In contrast, oocyte donors undergo medical treatment and receive no medical benefit but instead a financial benefit. As such, oocyte donors face a different risk-benefit decision with different ethical considerations, and thus this population may benefit from guidelines that address their unique situation. Particularly problematic with the disclosure of egg donation's long-term risks is that no longitudinal studies exist tracking this population's health (22). Current information on long-term risks is unclear. One study found the incidence of short-term major complications (some of which, like ovarian torsion or infection, might lead to infertility) to be $0.7 \%$, whereas another report found $9.6 \%$ of egg donors self-reporting diminished fertility after the procedure $(15,23)$. Neither finding provides definitive information on the risk to future fertility, yet it may be argued that responsible risk disclosure would include identifying this lack of clarity to potential donors.
The large proportion of websites (41\%) not following ASRM's suggested age minimum of 21 years to donate may also suggest exploitation. Presumably, this guideline seeks to ensure that donors are emotionally mature enough to make a decision that may impact their physical and psychological well being.

Affiliation with ASRM or SART is associated with higher adherence to the guidelines, but not completely so. For instance, of ASRM-member clinic websites and websites of agencies that have signed the SART agreement to abide by ASRM guidelines, 25.6\% paid premiums for traits, not complying with guidelines. Websites that pay more for traits were more likely to refer to or quote ASRM's guidelines on compensation, but often just mentioned the $\$ 5,000-$ $\$ 10,000$ compensation range that ASRM deems acceptable given justification-not the stipulations discouraging traitbased payment variation. In this way, websites not following this aspect of the guidelines may gain credibility to website users simply by quoting the section of the guidelines that they do follow.

These data have several implications for future policy. Our findings demonstrate that ASRM and SART do exert a measure of influence over its members by issuing guidelines and suggestions. Yet questions arise as to how effective such guidelines are at regulating behavior and whether, in certain instances, there may be a need for stronger regulatory mechanisms. Nonetheless, professional membership is voluntary and is not an option for agencies as they are not medical service providers or facilities. Our data found that agencies are less compliant, indicating a need for regulation of some kind, yet questions then arise of who should do the regulating and how and to what degree.

These data also have several implications for future research. Future studies could examine what factors predict the suggested age minimum requirements and disclosure of risks. The data also suggest the need to examine women who donated at less than versus at more than the age of 21 years, and to study differences in their concerns and perceptions about the donation process. Research could also probe public attitudes and perceptions concerning trait-based payment premiums and understandings of genetically inheritable traits.

This study design has several limitations. Although we evaluated the compensation offered and presentation of risks online, practices may differ on-site. We reported on sites that recruited online and displayed compensation, but not on sites that recruited online without displaying compensation. Furthermore, we attempted to simulate the path a potential donor might take online, yet she might instead search using other key words and phrases (e.g., "egg donor" or "selling eggs"), or may be recruited through other online channels such as digital banner ads (e.g., on Facebook) or classified ads (e.g., on craigslist).

Nonetheless, our study provides data on websites that have not been explored before, and suggests that egg donation agencies and clinics do not fully comply with professional guidelines on financial compensation of oocyte donors. This lack of compliance with ethical guidelines raises concerns as it suggests possible exploitation of donors 
(i.e., not disclosing risks alongside compensation and recruiting those less than age 21 years), and selective valuation of human traits (i.e., purchasing eggs themselves rather than compensating for the donor's time, inconvenience, and discomfort). A substantial portion of recruiting entities do not appear to follow ASRM's guidelines on compensation, although SART and ASRM endorsement appear to provide some beneficial effect, albeit incomplete. In sum, this research is the first to systematically explore ethical compensation guidelines in online egg donor recruitment and has critical implications for policy, practice, and research, suggesting needs for consideration of possible changes in guidelines and/or improvements in compliance, and monitoring by ASRM or others.

\section{REFERENCES}

1. Levine $A D$. Self-regulation, compensation, and the ethical recruitment of oocyte donors. Hastings Cent Rep 2010;40:25-36.

2. Steinbock B. Payment for egg donation and surrogacy. Mt Sinai J Med 2004; 71:255-65.

3. Begley S. Another reason to take SAT prep: get more for your eggs. Newsweek Available at: http://www.thedailybeast.com/newsweek/blogs/the-human-con dition/2010/03/24/another-reason-to-take-sat-prep-get-more-for-your-eggs. html. Accessed October 24, 2011.

4. Overpaid ovaries. The Economist. Available at: http://www.economist.com/ node/18586864. Accessed October 19, 2011.

5. Rabin CR. As demand for donor eggs soars, high prices stir ethical concerns. The New York Times. Available at: http://www.nytimes.com/2007/05/15/ health/15cons.html. Accessed October 19, 2011.

6. Sauer M. Oocyte and embryo donation 2006: reviewing two decades of innovation and controversy. Reprod BioMed Online 2006;12:153-62.

7. Ethical conduct in Assisted Reproductive Technology. AMA Code of Medical Ethics. Opinion 2.055. Available at: http://www.ama-assn.org/ama/pub/ physician-resources/medical-ethics/code-medical-ethics/opinion2055.page. Accessed October 19, 2011.

8. The Ethics Committee of the American Society for Reproductive Medicine. Financial compensation of oocyte donors. Fertil Steril 2007;88:305-9.
9. White $A E$. The morality of an internet market in human ova. J Value Inq 2006;40:311-21.

10. Klitzman R, Albala I, Siragusa J, Patel J, Appelbaum P. Disclosure of information to potential subjects on research recruitment web sites. IRB 2008;30: 15-20.

11. Luk J, Petrozza JC. Evaluation of compliance and range of fees among American Society Reproductive Medicine listed egg donor and surrogacy agencies. J Reprod Med 2008;53:847-52.

12. Holster K. Making connections: egg donation, the internet, and the new reproductive technology marketplace. Advances in Medical Sociology 2008 10:53-73.

13. Johnson KM. Fertility clinic, egg donation agency, and sperm bank policies. Fertil Steril 2011;96:877-9.

14. Census regions and divisions of the United States. Available at: http //www.census.gov/geo/www/us_regdiv.pdf. Accessed November 12, 2010.

15. Maxwell KN, Cholst IN, Rosenwaks Z. The incidence of both serious and minor complications in young women undergoing oocyte donation. Fertil Steril 2009;90:2165-8.

16. Zegers-Hochschild F, Adamson GD, de Mouzon J, Ishihara O, Mansours R, Nygren $K$, et al. The International Committee for Monitoring Assisted Reproductive Technology (ICMART) and the World Health Organization (WHO) Revised Glossary ART Terminology 2009. Hum Reprod 2009;24:2683-7.

17. Medline Plus: Ovarian Hyperstimulation Sydrome: http://www.nlm.nih.gov/ medlineplus/ency/article/007294.htm. Accessed on Febuary 15, 2012.

18. Repetitive oocytes donation. Practice committee for the American Society for Reproductive Medicine. Fertil Steril 2004;82(Suppl 1):S158-9.

19. Holland S. Contested commodities at both ends of life: buying and selling gametes, embryos, and body tissues. Kennedy Inst Ethics 2001; $11: 263-84$.

20. Lind PA, Luciano M, Horan MA, Marioni RE, Wright MJ, Bates TC, et al. No association between cholingergic muscarinic receptor 2 (CHRM2) genetic variation and cognitive abilities in three independent samples. Behav Genet 2009;39:513-23.

21. Advertising and Publicity. AMA Code of Medical Ethics. Opinion 5.02. Available at: http://www.ama-assn.org/ama/pub/physician-resources/medical-et hics/code-medical-ethics/opinion502.page. Accessed October 17, 2011.

22. Pearson $\mathrm{H}$. Health effects of egg donation may take decades to emerge. Nature 2006;442:607-8.

23. Kramer W, Schneider J, Schultz N. US oocytes donors: a retrospective study of medical and psychosocial issues. Hum Reprod 2009;24:3144-9. 